\title{
Den russiske togmyten
}

\author{
Brita Lotsberg Bryn \\ Oslo: Cappelen Damm Akademisk 2018 \\ 410 sider. ISBN 97882597177
}

Omtalt av Kristian Krohg-Sørensen [Journalist, tegneserieskaper, MA i russlandstudier fra Universitetet i Oslo, caruha@gmail.com]

Jernbanen har en særegen plass i Russland, og alle som har hatt gleden av å reise med tog i dette enorme landet vil nikke gjenkjennende til denne bokas tittel: Det er lett å gå med på at det finnes en myte basert på reiser over disse uendelige avstandene, i firemannskupé eller i åpen platskartny-vogn, med passasjerer av alle samfunnslag som stiger av og på mens storbyer, landsbyer, skoger og industrilandskap ruller forbi i vinduet. En skal heller ikke dykke dypt i den russiske litteraturen før en møter et forbipasserende tog: Tenk bare på alle tog- og stasjonsmotivene i Boris Pasternaks Doktor Zjivago eller Lev Tolstojs Anna Karenina. Fra den første russiske jernbanen i 1837 og helt til våre dager har russiske forfattere flittig tatt $\mathrm{i}$ bruk jernbanemetaforer for å skildre reiser i både tid og rom, isolerte samfunn inne i vogner eller på gudsforlatte stasjoner, prustende svarte jernhester eller «en dundrende ferd fra ingensteds til ingensteds", for å sitere den postsovjetiske forfatteren Vladimir Vojnovitsj.

Om mange vil nikke gjenkjennende til togmyte-tittelen, er jeg likevel redd for at undertittelen «en kulturfilologisk tilnærming til russiskspråklig jernbanefiksjon» vil virke avskrekkende på lesere som hadde håpt på en mer populærvitenskapelig framstilling av jernbanen i skjønnlitteraturen. Det ville i så fall være synd, for Brita Lotsberg Bryn holder det hun lover når hun skriver på omslaget at boka «henvender seg til spesialister og russiskstudenter så vel som til lesere med allmenn interesse for Russland, litteratur og kulturteori». Hennes lettfattelige språkføring, rike tekstutvalg og energiske referansehenvisninger gjør boka til en spennende reise - også for lesere som er mer interessert i det skjønnlitterære enn det akademiske aspektet.

Bryn er førsteamanuensis i russisk ved Universitetet i Bergen, og hennes akademiske forankring viser seg tydelig i introduksjonskapittelet, der begreper som myter, metaforer, troper og symboler drøftes med utgangspunkt i teorier av blant andre Roland Barthes og den russiske språkfilosofen Mikhail Bakhtin. Bryn har gjennomført sitt prosjekt ved nærlesning, analyse og ofte egne oversettelser av «jernbaneytringer». Hun presenterer både fiksjon og ikke-fiksjon, og benytter både "filologiske, litteraturteoretiske, kultursemiotiske og diskursanalytiske analyseverktøy»(s.15). De analyserte tekstene spenner fra Pusjkins poesi til postsovjetiske kortromaner, men 
underveis blir vi også presentert for billedkunst, fiksjons- og dokumentarfilmer, propagandaplakater, ideologiske sanger, protestdikt og avisartikler. Alle disse uttrykkene bidrar til å sette sammen et større bilde, samtidig som de underbygger Bryns teoretiske spørsmål om hvorvidt togmyten har bidratt til «å forme russisk, sovjetisk og postsovjetisk identitet og historieforståelse» (s. 333). Selv om hun vedgår at det er umulig å svare helt entydig på dette spørsmålet, gjør hun en solid jobb med å presentere bevis på at toget har spilt en viktig rolle i Russlands kollektive bevissthet i moderne tid.

Spesielt gjelder dette sovjettiden, der forfatteren hevder jernbanemyten har fulgt to hovedspor: Det ene, offisielle sporet har brukt jernbanen som symbol på framskritt (Marx' utsagn om at revolusjonen er historiens lokomotiv er det mest åpenbare), men også på makt (Stalin som lokomotivføreren) og på en teleologisk framstilling av Sovjetunionens reise mot kommunismen som utopisk endestasjon. Det andre sporet er litterært og populærkulturelt, og har forsøkt å korrigere denne propagandistiske, konstruerte virkelighetsoppfatningen, ofte med skjebnesvangre konsekvenser: Det mest kjente eksempelet er Boris Pasternaks Doktor Zjivago, der mange av hovedkarakterene ender opp på side- og blindspor i sine liv og jernbanen kan ses som symbol på adskillelse og død. Som kjent ble romanen slaktet av sovjetiske litteraturkritikere, og Pasternak ble presset til ikke å motta sin nobelpris.

En annen eksponent for dette litterære sporet var Andrej Platonov (1899-1951), en forfatter som også er blitt oversatt til norsk, men som kanskje er mindre kjent blant norske lesere. Bryn har viet et eget kapittel til «togsjelene» i Platonovs noveller Bessmertije (Udødelighet) og Sredi zjivotnykh i rastenij (Blant dyr og planter), hvorav den første med nød og neppe ble inkludert i den offisielle antologien fernbanetransport $i$ skjønnlitteraturen fra 1939 (utgitt av jernbanens eget forlag Transzjeldorizdat), og den andre ikke ble publisert før i 1998, lenge etter forfatterens død. Ved å analysere disse tekstene viser Bryn hvordan sovjettidens - og spesielt Stalin-tidens - forfattere måtte balansere hårfint i bruken av jernbanemetaforer, og hvor lite som skulle til for å feile.

Gjennom turbulente tøværs- og frostperioder etter Stalins død ble mange forfattere mestere i tvetydig metafor- og symbolbruk. I løpet av perestrojka-perioden ble togmetaforene igjen eskatologiske og illevarslende, og togene symboler på et samfunn i full oppløsning. Bryn gir oss blant annet en analyse av Venedikt Jerofeevs deliriske prosadikt Moskva-Petusjki, som ble publisert i samizdat-utgave rundt 1970, og ikke utkom offisielt i Sovjetunionen før i 1989. Jerofeevs burleske reise med lokaltog mellom hovedstaden og den forsofne forstaden Petusjki ender med hallusinasjoner, paranoia og mord - ikke i forstaden, men tilbake i Moskva, like ved Kremls murer.

Som Bryn påpeker i analysen av Viktor Pelevins Zjoltaja strela (Den gule pilen) fra 1993, fortsatte denne dystre symbolikken i den forvirrende tiden etter Sovjetunionens fall, og den har også forfulgt litteraturen inn i nåtidige bestselgere som Dmitrij Glukhovskijs dystopiske Metro-serie. Den utspiller seg riktignok på dypet av Moskvas tunnelbanesystem, men tar likevel i bruk mange av togmytens symboler og metaforer. 
Boka avsluttes med at forfatteren tar oss med på familietur til Moskva i mai 2018, der den russiske hovedstaden framstår overdådig festpyntet $i$ anledning Seiersdagen 9. mai - komplett med velfungerende kollektivsystem. Det virker opplagt at hun med denne skildringen påpeker en sammenheng mellom Fedrelandskrigsmyten i dagens Russland og jernbanemyten i førkrigstidens Sovjetunionen - en kollektiv myte som myndighetene ønsker monopol på, der den offisielle versjonen etter mange års gjentakelse er blitt så utbredt at det er liten plass til alternative stemmer.

Den russiske togmyten er et overflødighetshorn av en bok, og med sine henvisninger til nettsteder, musikk og filmklipp inspirerer den leseren til å fortsette utforskningen på egen hånd. Med en litt mer populærvitenskapelig innpakning ville den muligens kunne tiltrekke flere lesere enn den ser ut til å ta sikte på. 